\title{
Candidates rather than context shape campaign sentiment in French Presidential Elections (1965-2017)
}

\author{
Martin Haselmayer ${ }^{1}$
}

Accepted: 30 April 2021 / Published online: 4 June 2021

(C) The Author(s) 2021

\begin{abstract}
The manuscript explores whether and how the strategic context of elections and candidate attributes affect campaign sentiment. Studying five decades of French presidential elections, it provides the first longitudinal test of campaign tone outside the USA. Thereby, the paper examines concerns of an increase in negativity due to changes in electoral competition. It takes leverage from the electoral system, to study whether the strategic environment of elections (first vs. second rounds of elections) or candidate characteristics (ideology and outsider status) determine the use of positive and negative tone. To this end, the paper applies sentiment analysis to personal manifestos (professions de foi) issued by all candidates running in presidential elections (1965-2017) and validates the French Lexicoder Sentiment Dictionary for longitudinal studies of campaign tone. Results reject worries about an increase in negativity in French elections over time. Moreover, while context matters to some extent, candidate attributes are by far more important for explaining campaign sentiment in presidential races. The findings contribute to research on the role of sentiment in electoral competition and tackle broader issues related to the impact of positive and negative political communication for elections and democracies.
\end{abstract}

Keywords Campaign sentiment · Elections · Party competition · Professions de foi · Sentiment analysis · France

\section{Introduction}

Research into electoral competition has largely been fixated on two aspects of campaigns: issue competition (position or valence) and directional competition (positive or negative campaigning). The former centers on the question, whether political actors compete for votes by contrasting policy positions (Downs 1957) or issue

Martin Haselmayer

martin.haselmayer@uni-konstanz.de

1 Department of Politics and Public Administration, University of Konstanz, Universitätsstraße 10, 78464 Konstanz, Germany 
emphasis (Stokes 1963). The latter asks, whether candidates or parties focus their campaigns on their own strengths or others' weakness and failures (Lau and Brown Rover 2009; Haselmayer 2019). More recently, it has been argued that campaign sentiment, that is, the use of positive and negative language is an additional component at the disposal of political actors (Kosmidis et al. 2019; Crabtree et al. 2020). This manuscript adds to and extends this emerging literature by asking how politicians alter positive and negative sentiment in order to convey their messages to the public.

Studying campaign sentiment is important because candidates may use positive and negative language to sustain their portrayal of the status quo, including government performance, the state of the economy or the nation, which may provide important anchors for voting decisions in contemporary elections (Crabtree et al. 2020). Moreover, public and media increasingly worry about the amount and intensity of negative sentiment in contemporary politics, which may erode electoral turnout, undermine perceptions of democracy, or polarize the electorate (Mutz and Reeves 2005; Lau et a. 2007; Haselmayer et al. 2020). Thus, studying how political actors make use of positive and negative language can enrich our understanding of party competition and voting behavior and has broader implications for society and perceptions of democratic quality.

Yet, beyond negative campaigning (Lau et al. 2007; Lau and Brown Rover 2009; Haselmayer 2019) we know surprisingly little about how parties and candidates use positive and negative language during election campaigns. Previous studies on the use of campaign sentiment show that party attributes (incumbency and ideology), electoral competition (polarization, ideological proximity, competitiveness), and economic conditions affect campaign sentiment (Kosmidis et al. 2019; Crabtree et al. 2020). This suggests that political actors are strategic about the use of sentiment, yet it does not tell us whether concerns about an ever-growing increase in negativity are justified, nor if parties and politicians are responsible for such a trend. We also lack an understanding of how individual candidates make use of positive and negative language during elections or whether campaign sentiment hinges on the strategic setting of campaigns or candidate attributes.

This manuscript addresses these gaps by examining campaign sentiment in French presidential elections. It thereby provides the first longitudinal study of campaign sentiment - and the presumed increase in negativity-in elections outside the USA. The study also breaks new ground by focusing on the electoral strategies of individual candidates. Drawing on the peculiarities of the French electoral system and two-round elections further enables testing whether the strategic environment of elections (first vs. second rounds) or candidate characteristics (ideology and outsider status) determine the use of positive and negative campaign tone.

The study draws on a novel dataset covering 121 professions de foi (personal manifestos) of all candidates running in all direct presidential elections of the Fifth Republic (1965-2017). It applies sentiment analysis (Young and Soroka 2012; Haselmayer and Jenny 2017) to identify negative and positive campaign communication and provides an extensive validation of the French Lexicoder sentiment dictionary (Laval and Pétry 2016). Results reject worries about an increase in negativity in democratic politics as observed in US elections (e.g., Geer 2006; West 2017). 
Moreover, first rounds of elections entail less positive sentiment than second rounds, yet the effect vanishes, once we control for candidate attributes. Thus, rather than adapting campaign tone to a changing strategic context, individual attributes, such as ideology and outsider status determine if candidates use positive or negative language. In line with prior research (Kosmidis et al. 2019; Crabtree et al. 2020), these results suggest that candidates strategically use campaign sentiment in their personal manifestos.

\section{Campaign sentiment}

Research on political competition has focused on two main components: whether campaigns deal with substantive policy matters or valence issues (Downs 1957; Stokes 1963) and whether parties or candidates focus on themselves or their opponents (e.g., Lau and Brown Rover 2009; Nai and Walter 2015; Haselmayer 2019). The latter is typically associated with a distinction between positive and negative campaign strategies. However, it is tied to the target of political communicationthus studying whether and how parties and candidates talk about opponents.

Yet, despite directly criticizing their political competitors, parties and candidates can use positive and negative language to strengthen their policy claims or for framing a particular issue, such as migration or the economy (Kosmidis et al. 2019; Crabtree et al 2020). To provide examples from actual presidential campaigns, incumbent president Valérie Giscard D'Estaing drew a very positive picture of his term in the 1981 campaign stating that "production has augmented" and "the number of jobs has gone up." These statements use positive sentiment to draw the attention toward a successful record in government (on a position issue). Politicians may also use negative sentiment to decry the state of the country. In his profession de foi for the 2007 presidential elections, Jean-Marie Le Pen, deplored that "France is ruined, demoralized, and humiliated (...)." ${ }^{2}$ Whereas this statement obviously uses negative language, it extends any definition of negative campaigning as it does not contain any direct reference about whom to blame (e.g., Geer 2006; Haselmayer 2019). To the contrary, Philippe Poutout's 2017 manifesto blames François Hollande's “catastrophic presidency." The statement contains both, negative language and a directional reference. Hence, in conceptional terms, it subsumes negative sentiment and negative campaigning. Accordingly, campaign sentiment is neither confined to positive or negative campaigning nor to policy or valence issues. It subsumes both of these strategies: by linking negative or positive language to (i) political actors (positive or negative campaigning) and/or (ii) content (policy or valence).

For what is more, positive and negative language conveys emotions, which are important in political decision-making and can contribute to voter behavior (e.g., Marcus 2000, 2010). Negative emotions, such as fear, may alter voting decisions,

\footnotetext{
1 Own translation: Original quotes: "La Production nationale a agumenté (...)." "Le nombre des emplois s'est accru (...)."

2 Own translation: Original quote: "Aujourd'hui, la France est ruinée, démoralisée et humiliée (...).”
}

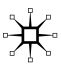


whereas positive ones, such as enthusiasm, have the potential to foster pre-existing preferences (Brader 2005, 2006). Overall, this suggests that both, positive and negative emotions are important in contributing to perceptions of campaigns, opinion formation and voting decisions. Framing research has demonstrated how positive and negative portrayals of the same facts may alter how humans process information and make sense out of it (Tversky and Kahnemann 1981; Druckman 2004). Psychological and linguistic research shows that these effects can be triggered by the usage of positive and negative language (e.g., Pennebaker 1993). Hence, political actors can use campaign sentiment to alter emotional perceptions of the status quo, themselves and their opponents in order to maximize electoral gains. Therein resides the importance of studying campaign sentiment.

\section{Determinants of campaign sentiment in French presidential elections}

Empirical data on US elections show that campaigns have become increasingly negative over time (e.g., Geer 2006; West 2017). This trend has been linked to growing electoral volatility and competition, parties catering to the demands of the news media, or polarization-challenges that most West European countries have witnessed in the past decades. As campaigns have been converging toward a global standard (Plasser and Plasser 2002), it has been argued that such trends should be observable in other countries across the world. Yet, as of now, we lack empirical evidence that long-term changes in campaign sentiment apply outside the USA.

Increased electoral volatility and intensified party competition in Western European countries have been linked to more offensive and thus negative campaigns (Walter 2014). Thus, parties are expected to chase undecided voters by running more offensive campaigns, which should coincide with an increase in negative campaign sentiment (Walter 2014). The growing importance of traditional and social media for political communication is another likely driver of more negativity in campaigns as journalists, editors and the public prefer negative over positive information (Galtung and Holmboe Ruge 1965). Hence, parties and politicians seeking to attract large audiences to convey their messages can achieve this goal if they cater to these demands-i.e., by incorporating news factors, such as negativity - to increase the audience of their campaign messages (Haselmayer et al. 2019). Based on these arguments, I expect a net-increase in negative campaign tone over time.

Hypothesis 1 Campaign sentiment has become more negative over time.

Another expectation deals with the particular strategic environment of tworound elections (e.g., Duverger 1951). Drawing on spatial models of party competition, Laver et al. (2006) argue that candidates (and parties) should benefit from presenting a more pronounced profile in first round elections to leverage support from their respective (left or right) pool of voters. Second runs, in turn, typically oppose (moderate) candidates from the left and the right. These candidates will increase their chances of winning by moving closer to the median voter 
(Laver et al. 2006). This argument has been useful for explaining Lionel Jospin's defeat in the first round of the 2002 presidential election. Jospin's attempt to present a centrist profile in the first round undermined support from leftist voters, which he could not compensate by capturing moderate or center-right votes (Esquenazi 2003; Jaffré 2003). In terms of campaign sentiment, this could indicate stronger benefits for negative tone in first rounds of elections, for example to shift an opponents' ideological position in order to undermine their electoral support (Harrington and Hess 1996). As argued above, candidates in second rounds should be more likely to present rather moderate-and thus more similar-policy profiles to target the median voter. If candidates present similar policies, voters will find it harder to differentiate between them. Hence, political actors will want to signal to voters how much they care about a given issue and show their commitment to it. One way to do so is by relying on positive sentiment. Doing so increases the weight political actors attach to an issue and makes it more costly to fail to deliver it once elected (Kosmidis et al. 2019). Accordingly, candidates should use positive sentiment to attest of their commitment to a policy if they seek to increase their credibility in the voters' eyes when policy proposals are similar. These strategic incentives suggest that first rounds of elections should feature more negative campaign sentiment than second rounds.

Hypothesis 2 Campaign sentiment in first rounds is more negative than in second rounds.

Beyond strategic incentives, differences in-between first and second rounds are likely to represent variation in candidate attributes, such as ideological extremeness and outsider status. First rounds feature more and more ideologically diverse candidates. In the French context, they typically include a broad range of ideologically extreme candidates and outsiders without electoral prospects. Both of these factors have been associated with the use of negative campaign communication.

Crabtree et al. (2020) argue that ideologically extreme parties should use a more negative tone than moderate ones because the former are more likely to benefit if voters perceive the status quo more negatively. The argument is linked to a parties' low electoral prospects: being and (probably) remaining out of government, ideologically extreme parties and candidates have less to gain from crafting own policy proposals or by presenting a policy agenda for the next term. Rather, they gain electoral support from drawing a pessimistic picture of the status quo or from their fundamental rejection of the established political system (Crabtree et al. 2020). On a similar note, Kosmidis et al. (2019) find that the use of positive sentiment coincides with lower levels of ideological polarization at the partysystem level, which suggests that politicians communicate more positively in the absence of ideological antagonisms. These accounts also mirror results from negative campaigning research, showing that ideologically extreme parties are more negative toward their opponents than moderate ones (Walter et al. 2014; Valli and Nai forthcoming). 
Outsider candidates suffer from strategic disadvantages in terms of resources and attention, both of which are crucial for their electoral success. Running a negative campaign can help candidates to mitigate this shortcoming by raising visibility and awareness to their candidacy. Psychological research demonstrates that people pay more attention to negative than to positive information and that the negative bits of information contribute more to human decisions (e.g., Baumeister et a. 2001; Soroka 2014). The 'negativity bias' in human cognition and information processing helps parties to attract public and media attention. As journalists and editors prefer negative news (Galtung and Holmboe Ruge 1965), they are more likely to report on negative than on positive party messages (Haselmayer et al. 2019).

Accordingly, there are good reasons for ideologically extreme and outsider candidates to rely on negative sentiment in their campaigns:

Hypothesis 3 Ideologically extreme candidates use more negative campaign sentiment than moderate ones.

Hypothesis 4 Outsider candidates use more negative campaign sentiment than established ones.

\section{Case selection, data and methods}

The study focuses on campaign tone in France, yet results should improve the understanding of the strategic use of sentiment in Western Europe and countries with similar electoral rules. The French semi-presidential system features direct presidential elections following majority rule. If no candidate obtains an absolute majority of the votes in the first round, a second ballot opposes the top two candidates two weeks later. This feature of the French electoral system provides a unique setting for in-depth testing of the rationales outlined above. Beyond a mere comparison of campaign tone in first and second rounds, the analyses will specifically investigate the behavior of candidates moving to the second round. Thus, it leverages variation between electoral rounds to investigate campaign sentiment of successful candidates.

The paper draws on a novel dataset on French presidential elections (1965-2017). It uses data collected by the CEVIPOF electoral archives (Archives électorales $d u$ CEVIPOF Sciences Po) covering, among others the personal manifestos for all candidates running in presidential elections between 1965 and 2012. These data are supplemented with own collections for the most recent 2017 campaign using official party and candidate webpages to cover all direct presidential elections in the Fifth Republic. The final dataset contains 121 professions des foi (personal manifestos) issued by all 101 candidacies from 70 distinct candidates running in these elections.

Like on any other traditional communication tool, France has imposed strict regulations for the professions de foi. ${ }^{3}$ These include their size, paper type and weight as

\footnotetext{
${ }^{3}$ Article 15 of Decree $n^{\circ} 64-231$ (14.03.1964) and Article 19 of Decree ${ }^{\circ} 2001-213$ (08.03.2001) specifically deal with the professions de foi.
} 
well as the ban of reproducing the colors of the French flag. The government covers the costs of distributing all personal campaign manifestos to all voters together with the official voting bulletin. ${ }^{4}$ Despite recurrent criticisms of the inefficiency and high costs, attempts to suppress the delivery or to replace it have been unsuccessful. ${ }^{5}$ Thus, each voter gets in touch with these documents-at least when throwing them in the bin.

Yet, despite their proliferation and their potential relevance given their penetration, there is only anecdotal and incidental evidence on their use. Existing studies are based on a small set of districts and elections and cover specific aspects of campaign discourse. This includes the rhetoric of addressing citizens (Rigat 2010) or democracy (Morin and Sourd 2007), electoral proximity (Paoletti 2005), lexical distance (Rampon 2006), or gender-sensitive language (Lévêque 2005). Yet, there is no systematic evidence on how candidates use these "private manifestos" in their campaigns. Bonhomme (2016) argues that these are documents of "auto-promotion" containing information on candidates, their programs and preferences as well as their rhetorical style. Whereas fewer people effectively read these documents in contemporary elections, survey-evidence from the most recent 2017 elections suggests that they are still among the most important sources for voters to learn about the campaign. ${ }^{6}$ Beyond their electoral impact, they are valuable for understanding party competition as they summarize the principle campaign strategy of individual candidates for both electoral rounds. Moreover, in contrast to more recent communication tools, such as social media, they enable longitudinal studies of election campaigns.

\section{Sentiment analysis of campaign tone}

The manuscript uses sentiment analysis, that is the automatic detection of positive and negative language in texts (e.g., Young and Soroka 2012; Haselmayer and Jenny 2017). It employs the French version of the Lexicoder sentiment dictionary to identify positive and negative language (Duval and Pétry 2016). Thus, by retrieving positive and negative dictionary words in each profession de foi, it determines the overall sentiment of texts. Recent studies successfully apply sentiment dictionaries to study campaign sentiment in party communication and leader speeches (e.g., Haselmayer and Jenny 2017; Kosmidis et al. 2019; Crabtree et al. 2020).

\footnotetext{
${ }^{4}$ However, each candidate or party is responsible for printing them, which may impose limits to those with lower resources even though the incurred costs may be reimbursed after the election for candidates obtaining at least $5 \%$ of votes.

${ }^{5}$ A 2015 ministerial report issued jointly by the Ministry of Finance and the Ministry of Interior affairs was the latest initiative in this respect. The report evokes that seven percent of the profession de foi could not be delivered in the 2014 European elections. The costs for the 2012 presidential election campaign attained 120 million euros. The document also refers to previous unsuccessful attempts to can the personal manifestos. Link. https://bit.ly/2K2GCzp [25.07.2019].

${ }^{6}$ In a representative exit poll for the 2017 legislative election (OpinionWay 2017), 24\% of respondents declared that professions de foi were among the three most important sources for gathering information about candidates. This was the second highest score after television (49\%), but ahead of online media (23\%), paper news (20\%) or radio (17\%). Results are similar for presidential elections.
} 
The application follows Young and Soroka (2012), who compute an overall sentiment score taking both positive and negative words as well as the total number of words in a document into account. For each document $(d)$, the sentiment score $(s)$ is the proportion of positive dictionary words $\left(w_{p}\right)$ in a document's total words $(w)$ minus the proportion of negative words $\left(w_{n}\right)$ in a document's total words $(w)$ :

$$
s_{d}=\frac{N\left(w_{p}\right)}{N(w)}-\frac{N\left(w_{n}\right)}{N(w)}
$$

Accordingly, a sentiment score of +4.5 indicates that a document contains 4.5 percentage points more positive than negative words. Proportions account for varying text length, which could result in spurious results as longer documents typically contain more positive and/or negative words.

\section{Validating the Lexicoder Sentiment Dictionary for French presidential elections}

The French version of the Lexicoder dictionary has been adapted from the English language edition (Duval and Pétry 2016). It contains 2867 negative words and 1284 positive ones. The total number of words (4151) is slightly below that of the English edition (4567).

Duval and Pétry (2016) have applied the dictionary to texts from Quebecois newspapers between 2007 and 2014. However, there is no prior evidence that it is suitable to analyze political communication in French elections. Even less so covering a substantive time period, which obviously imposes limits to pre-established word lists, given the transformation and evolution of language over time.

A central claim in the text-as-data literature is that all applications require extensive validation against human coding (Grimmer and Stewart 2013). This applies particularly to transferring existing resources, such as dictionaries or training data for machine learning applications to new (con)texts of application (Haselmayer and Jenny 2017; Rudkowsky et al. 2018). Therefore, this section validates the dictionary against human coders. To this end, a quota random sample of hundred sentences has been drawn from the original corpus. The quota makes sure that the sample contains at least ten sentences from each decade to evaluate the performance across time. The ability of the dictionary to produce valid sentiment estimates for the data under study is evaluated against French coders recruited on a crowdsourcing platform.

Each sentence was coded by five contributors, ${ }^{7}$ who were asked to determine whether a sentence contains predominantly positive (1), neutral (0) or negative $(-1)$ sentiment. Following theories on group decisions, the overall coding was

\footnotetext{
7 Coders have to pass entry tests, and their performance is monitored throughout the coding process based on a pre-determined sentiment score. Only contributors with a minimum accuracy of $70 \%$ correct answers were retained. Additionally, I check answer distributions and set speed traps (minimum answer time) to identify cheaters or bots (people/programs who try to maximize benefits by providing random answers).
} 


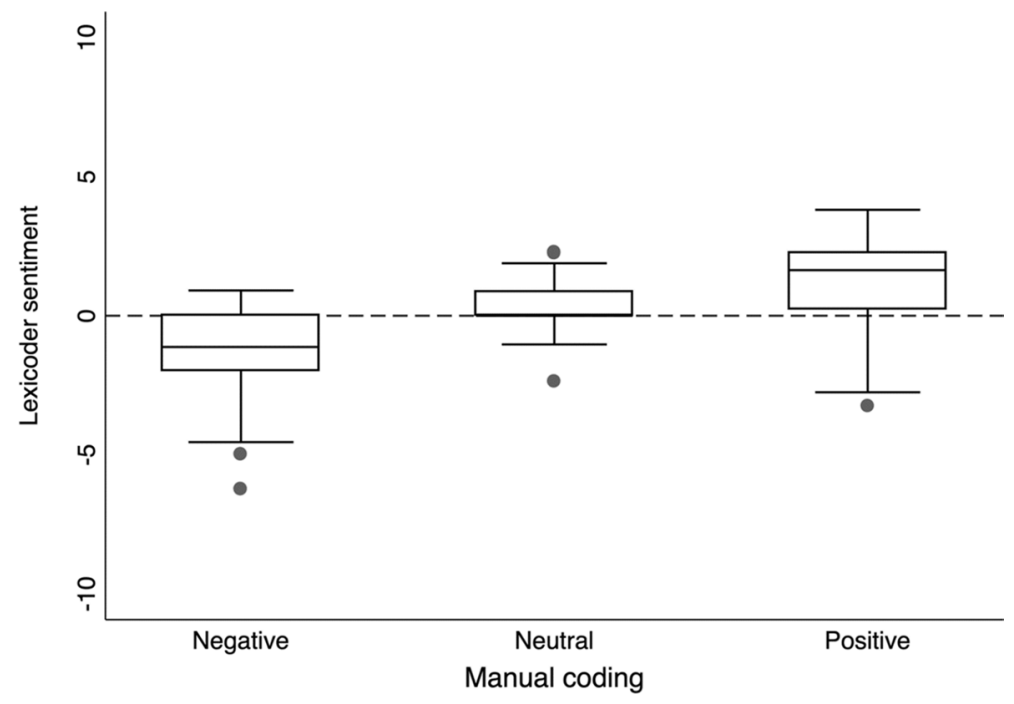

Fig. 1 Comparing Lexicoder sentiment scores to aggregated crowdcoding

determined by simple majority rule (de Condorcet 1785). This follows the assumption that the aggregated majority decision of a group of layperson is able to match or even outperform expert judgment. Evidence from similar applications confirms that aggregated crowdcoding is indeed able to replicate experts or trained coders (Haselmayer and Jenny 2017, 2018).

I subsequently compare aggregated coding decisions to the Lexicoder sentiment scores. ${ }^{8}$ This replicates validation practices of previous applications of the dictionary, yet at the level of news articles (see Young and Soroka 2012 and Duval and Pétry 2016). Figure 1 presents the results, which demonstrate that the automated scores are able to replicate human coding decisions-even at the sentence-level. Despite a slight positive bias, the dictionary scores accurately match human coding of sentiment. Additional checks in the appendix, which also provides information on text pre-processing ("Appendix C"), confirm its ability to provide valid sentiment estimates at the sentence-level and across the research period.

To be sure, the sentence-level constitutes a very conservative test. The approach will likely misclassify sentiment of short sentences with positive or negative meaning that is not captured by dictionary entries. Moreover, automated approaches often struggle to correctly determine positive or negative meaning when sentences contain reversed sentiment (i.e., due to negation), irony, sarcasm or metaphors. The presence of such language can be crucial at the sentence-level. However, I assume that potential sources for misclassification should apply to positive and negative sentiment

\footnotetext{
${ }^{8}$ I relied on R's quanteda package (Benoit et al. 2018) for importing, pre-processing and applying the dictionary. Pre-processing was minimal : documents were tokenized, cleaned, and the built-in stop-word list was used with slight adaptions accounting for common named entities, such as "France."
} 
alike and across all documents. Therefore, the performance of the dictionary should be more accurate at the document-level. Overall, validation (also see "Appendix C") provides good evidence that the French Lexicoder sentiment dictionary produces accurate estimates for studying campaign sentiment in fifty years of presidential elections in France.

\section{Dependent variable}

The subsequent empirical analyses apply the dictionary to obtain the sentiment score described above for each of the 121 professions de foi issued in the ten presidential elections (1965-2017). Additional analyses use the share of negative and positive words as dependent variable (Tables 6 and 7 of "Appendix B"). This strategy enables further analyses of the theoretical mechanisms outlined above.

\section{Independent variables}

To test for a time trend in negativity (HI), I simply include a count variable for all elections (1-10), starting from the first edition in 1965 (1) until the most recent one in 2017 (10). To account for general differences between election rounds (H2), a binary variable indicates first (0) and second (1) rounds. The dichotomous (0/1) measure of ideological extremeness (H3) uses information from the Chapel Hill Expert Survey (Polk et al. 2017) and party families to identify moderate (0) and extreme (1) candidates. It further uses contextual information and Wikipedia, as proxies if no other information was available (see Valli and Nai forthcoming for a similar strategy). Whereas this measure is far from ideal, there is no valid alternative given the long time period and a large number of candidates from small parties that are not included in traditional data sources, such as the CHES. On the left, extreme candidates are those representing communist and Marxist parties or ideologies (i.e., Parti Communiste Français, Lutte Ouvrière) or radical left parties, such as La France Insoumise. On the right, the category contains candidates from (or ideologically close to) the Front National/Rassemblement National. Table 2 in the "Appendix" provides an overview of candidates and their ideological coding. To determine outsider status (H4), I use a candidate's first-round vote shares. Candidates obtaining less than two percent of the votes are coded as outsider $(0 / 1) .{ }^{9}$ As election results typically mirror a candidate's general status in terms of public visibility and attention before the election, this is a reasonable proxy - in particular for identifying the large group of candidates without electoral prospects (i.e., more than a quarter of candidates obtained less than two percent of the votes). Another dichotomous variable identifies candidates that successfully moved to the second round $(0 / 1)$. This enables tests of within-candidate variation between first and second rounds and provides an additional test of the theoretical arguments based on a restricted sample ( $n=40: 20$ candidates $\times 2$ rounds).

\footnotetext{
9 To check the robustness of this indicator, additional analyses use 1\%, 3\% and 5\% thresholds for outsiders, which does not affect the results (Appendix B, Table 8).
} 
The hypotheses are tested in an ordinary least squares regression design with candidate-clustered standard errors. The models further account for individual, institutional or contextual factors that may trigger variation in campaign tone. This includes dummies for candidate gender $(0 / 1)$, frontrunners in the electoral race $(0 / 1)$ or elections following a period of cohabitation $(0 / 1)$. To account for objective changes to the status quo (Crabtree et al. 2020), all models further account for economic growth, which is the annual percentage increase in gross domestic product expenditures taken from the World Bank's Open Data archive (World Bank 2021). This variable is lagged by a year, to ensure it reflects the economic conditions at a time before candidates wrote their personal manifestos. To account for variation in campaign sentiment of longer and shorter professions de foi, a control for text length (number of words) enters the models. The Appendix provides descriptive information for the variables of interest (cf. Appendix Table 3).

\section{Results}

Data on presidential elections (1965-2017) contain 121 professions de foi issued by 101 candidacies from 70 candidates running in ten elections. Presidential campaigns opposed candidates from 43 different parties as well as nine independents without party affiliation. ${ }^{10}$

An average document contains roughly 1600 words (standard deviation of 780). François Mitterrand provided readers with the most extensive document in the first direct presidential elections (4100 words), whereas René Dumont's 1974 manifesto was the shortest in fifty years (250 words). Turning to the sentiment of the documents, they contain, on average, roughly 2.4 percentage points more positive than negative references (standard deviation of 2.2). This finding is in line with prior research on campaign sentiment and could indicate that political actors predominantly employ positive sentiment to increase the credibility of their claims (Kosmidis et al. 2019). Inspecting the manifestos of successful candidates shows that their first-round editions are longer than those of second rounds, on average (mean words of 1411 and 812, respectively).

Georges Pompidou's 1969 second round profession de foi was the most positive manifesto ( +9.5 sentiment score). Besides striking an utterly positive balance of the previous term, where he served as prime minister under president De Gaulle, he spent almost a quarter of his short manifesto to thank voters for their trust and confidence in the first ballot. Beyond that, he lists numerous, mostly vague plans, all of which bearing (only) positive consequences. Thus, he wants to "conserve solid institutions and a stable executive," "assure economic progress," "raise the standard of living for all" or "improve the situation of workers." 11

${ }_{10}$ Only candidates with no link to a party are coded as independent.

11 Own translation. 
The most negative personal manifesto stems from Philippe Poutout's 2017 campaign (- 2.2 sentiment score). Candidate of the extreme left, ${ }^{12}$ he railed against candidates from established parties, which have implemented "antisocial" policies and François Hollande's "catastrophic" presidency. He blames capitalism's responsibility for "wars, terrorist attacks, crisis, unemployment, misery (...)" and proposes to "sweep the system" or to "abolish the presidency" altogether.

Figure 2 provides first insights into the use of campaign sentiment in French candidates' personal manifestos across time. It plots the mean sentiment scores of all candidates running in an election. On average, the use of positive and negative language is very stable, which clearly contradicts Hypothesis 1. The 1969 election exhibits the most positive sentiment score $(+3.2 \%$ positive sentiment $)$, that of 2012 was least positive ( +1.8 positive sentiment), which confirms prior evidence that this edition was particularly contested (Labbé and Monière 2014).

Turning to differences between first and second electoral rounds (H2), Fig. 3 shows that second rounds of elections were, on average, more positive than first rounds $(+2$ for first rounds and +4.2 for second rounds). These differences are particularly strong for elections in the 1960s and those between 1988 and 2002. The second round of the 1981 election has the least positive sentiment score in the research period $(+1.36)$. This election saw Mitterrand and Giscard D'Estaing fiercely competing for the presidency. Variation between election rounds is negligible for several elections, in particular for the most recent ones. The right panel of Fig. 3 further shows that all runner-offs in the three most recent elections have sentiment scores below the mean suggesting that electoral competition in second rounds got more negative.

To be sure, the differences observed above could also stem from candidate attributes, such as ideological extremeness and outsider status. Figure 4 plots campaign sentiment across these categories. It shows that both affect campaign tone: moderate candidates are clearly more positive than extreme ones ( +3.17 vs. +0.72 sentiment), as are candidates with larger electoral prospects compared to mere outsiders $(+2.01$ vs. + 1.14) (Fig. 4). Importantly, these variables are not correlated $(r=0.08)$.

Looking into the behavior of successful candidates provides mixed evidence: in six out of ten elections, their first-round manifestos were more positive, and in four elections the opposite applies. On average, first round manifestos of successful candidates where slightly less positive than those of second rounds (mean values of 3.73 and 4.2 respectively). More generally, descriptive evidence seems to indicate that candidate attributes are more important in determining campaign sentiment than strategic incentives emerging from variation between election rounds alone.

To provide a more systematic test of our hypotheses, I ran ordinary least squares regression models of campaign sentiment using candidate-clustered standard errors. Results presented below are robust across different model specifications, such as bootstrapped standard errors accounting for small sample size, when re-running the analysis separately for positive and negative sentiment or when adapting the threshold for outsider candidates (cf. "Appendix B").

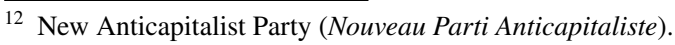


Table 1 Explaining campaign sentiment in French Presidential elections (1965-2017)

\begin{tabular}{|c|c|c|c|c|}
\hline & Model 1 & Model 2 & Model 3 & Model 4 \\
\hline Time trend & $\begin{array}{l}-0.08 \\
(0.11)\end{array}$ & $\begin{array}{l}-0.01 \\
(0.09)\end{array}$ & $\begin{array}{l}-0.10 \\
(0.24)\end{array}$ & $\begin{array}{l}-0.13 \\
(0.17)\end{array}$ \\
\hline Election round & $\begin{array}{l}1.10^{+} \\
(0.62)\end{array}$ & $\begin{array}{l}0.21 \\
(0.61)\end{array}$ & $\begin{array}{l}-0.17 \\
(0.74)\end{array}$ & $\begin{array}{l}-0.06 \\
(0.71)\end{array}$ \\
\hline Extreme & - & $\begin{array}{l}-1.65^{* * * *} \\
(0.32)\end{array}$ & - & $\begin{array}{l}-0.58 \\
(0.37)\end{array}$ \\
\hline Outsider & - & $\begin{array}{l}-0.97 * \\
(0.38)\end{array}$ & - & - \\
\hline Frontrunner & - & $\begin{array}{l}1.65^{* * *} \\
(0.40)\end{array}$ & - & $\begin{array}{l}1.87 * * \\
(0.52)\end{array}$ \\
\hline Female & - & $\begin{array}{l}0.23 \\
(0.37)\end{array}$ & - & $\begin{array}{l}0.79 \\
(0.63)\end{array}$ \\
\hline Cohabitation & $\begin{array}{l}-0.07 \\
(0.44)\end{array}$ & $\begin{array}{l}-0.03 \\
(0.32)\end{array}$ & $\begin{array}{l}0.10 \\
(0.92)\end{array}$ & $\begin{array}{l}0.33 \\
(0.64)\end{array}$ \\
\hline GDP growth (lagged) & $\begin{array}{l}-0.01 \\
(0.18)\end{array}$ & $\begin{array}{l}0.03 \\
(0.14)\end{array}$ & $\begin{array}{l}0.07 \\
(0.34)\end{array}$ & $\begin{array}{l}0.04 \\
(0.15)\end{array}$ \\
\hline Text length & $\begin{array}{l}-0.00^{* * *} \\
(0.00)\end{array}$ & $\begin{array}{l}-0.00 * \\
(0.00)\end{array}$ & $\begin{array}{l}-0.00 * * \\
(0.00)\end{array}$ & $\begin{array}{l}-0.00 * * * \\
(0.00)\end{array}$ \\
\hline Constant & $\begin{array}{l}4.46^{* * *} \\
(1.16)\end{array}$ & $\begin{array}{l}3.74 * * * \\
(0.97)\end{array}$ & $\begin{array}{l}5.51^{+} \\
(2.54)\end{array}$ & $\begin{array}{l}4.53 * \\
(1.60)\end{array}$ \\
\hline Observations & 121 & 121 & 40 & 40 \\
\hline Adjusted $R^{2}$ & 0.23 & 0.48 & 0.08 & 0.28 \\
\hline
\end{tabular}

Candidate-clustered standard errors in parentheses, ${ }^{+} p<0.10$, ${ }^{*} p<0.05,{ }^{* *} p<0.01,{ }^{* * *} p<0.001$

Mean sentiment

in French presidential elections

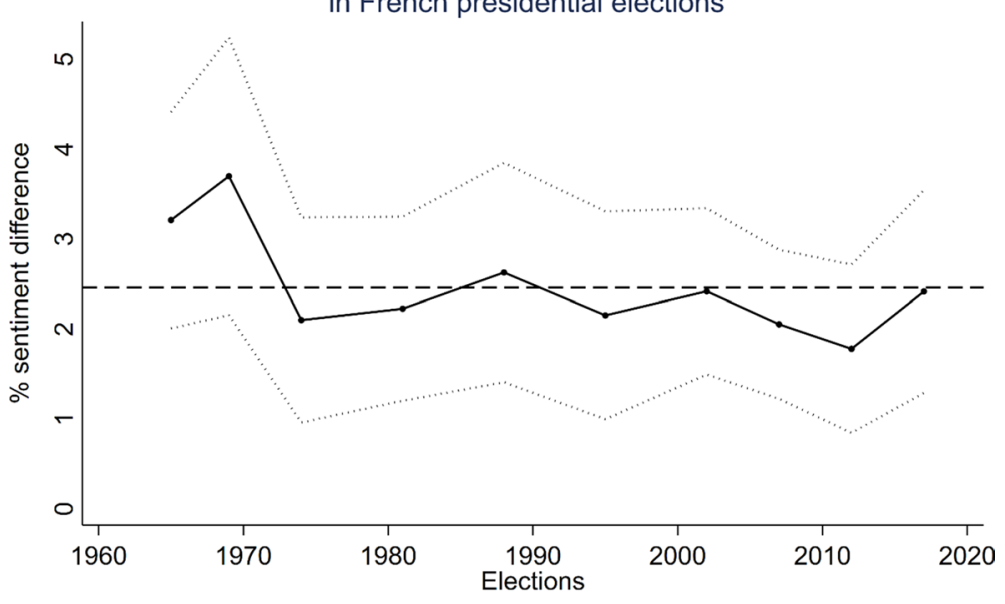

Note: Dashed line indicates mean across all elections. Dotted lines indicate standard deviation

Fig. 2 Campaign sentiment in French presidential elections (1965-2017) 

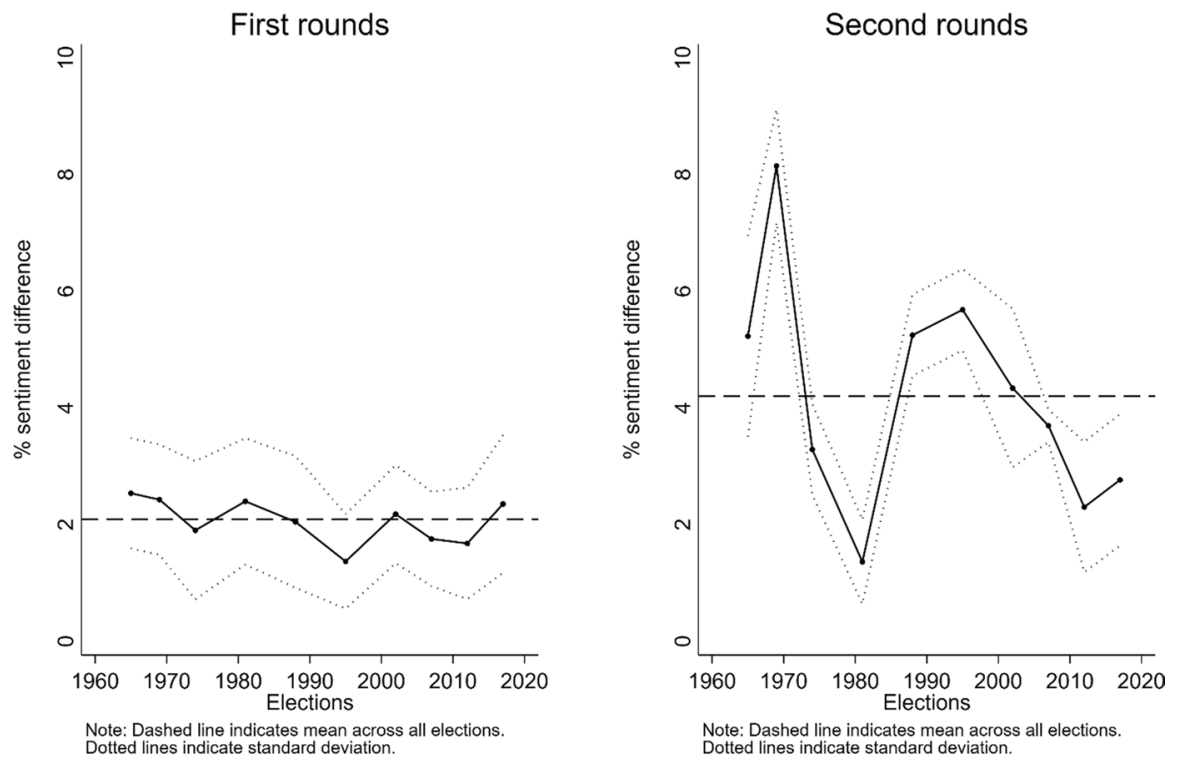

Fig. 3 Campaign sentiment in first and second rounds of elections (all candidates)

(I) Ideology

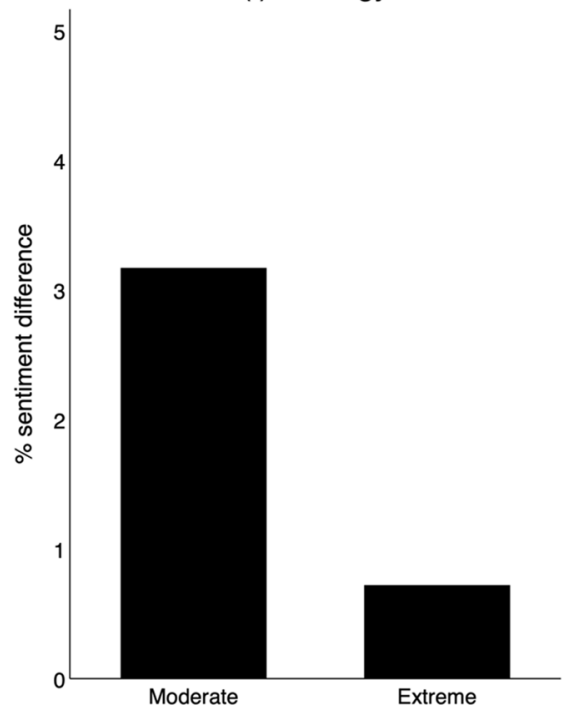

(II) Outsider status

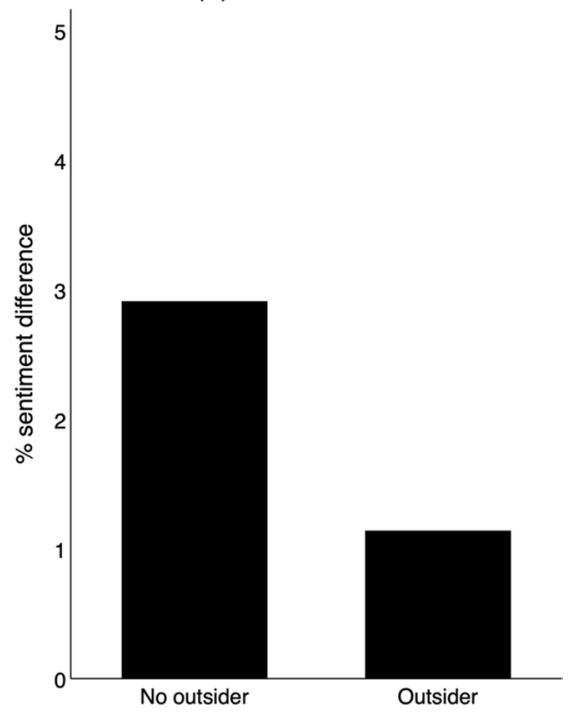

Fig. 4 Campaign sentiment candidate ideology and outsider status

Model 1 tests for a time trend in campaign sentiment and checks differences between electoral rounds whilst controlling for economic conditions, cohabitation and text length. Model 2 adds candidate attributes. Models 3 and 4 repeat these 
analysis based on the reduced sample of successful candidates (excluding the outsider dummy as none of them made it to the second round) (Table 1).

Whereas all models show a negative coefficient for the time trend indicator, the effect is minimal and far from reaching conventional levels of significance. Thus, there is no support for Hypothesis 1: elections have not turned more negative over time. Turning to our second expectation, Model 1 suggests that second rounds of elections are more positive than first rounds with an 1.1 increase in campaign sentiment $(p<0.1)$. Yet, the effect vanishes, once I control for candidate attributes. Hypothesis 2 therefore has to be rejected as well. Model 2 shows that candidate attributes are by far more important than the strategic environment of first and second rounds. This confirms Hypotheses 3 and 4: extreme candidates $(-1.65$, $p<0.001)$ and outsiders $(-0.97, p<0.05)$ are less positive than moderate ones or those with better electoral prospects, respectively.

Limiting the analysis to successful candidates significantly reduces the set of observations, yet results from Models 3 and 4 corroborate those obtained from the full sample: candidates, rather than context shape campaign sentiment even if the effect for extreme candidates does not reach statistical significance here. ${ }^{13}$

Turning to the control variables, there is strong and ubiquitous support for frontrunners being more positive than other candidates $(+1.65$ based on Model $2,+1.87$ based on Model 4, $p<0.001)$. Campaign tone of female candidates is somewhat more positive, yet the effect is rather weak and fails to reach conventional levels of statistical significance. There is no effect that manifestos issued in campaigns following cohabition are different in terms of campaign tone. Interestingly, coefficients are negative for all candidates and positive for runners-off, which suggests a somewhat different logic for both groups. In contrast to prior research (Crabtree et al. 2020), there is no evidence that the status quo affects campaign tone, yet separate analyses of positive and negative sentiment show that runners off are less negative when the economy is growing (cf. "Appendix B": Table 8, Models 3 and 4).

\section{Discussion}

During elections, parties and candidates dispose of a variety of strategies to appeal to voters and partisans. They may present their policy platforms, emphasize their best issues or show that they care about voters' concerns. More recently, it has been argued that campaign sentiment - the use of positive and negative language-constitutes an additional component of party campaigns (Haselmayer and Jenny 2017; Kosmidis et al. 2019; Crabtree et al. 2020). Adding to and extending this emerging research, the manuscript has investigated campaign tone in fifty years of French presidential elections. Studying candidates' personal manifestos, it provides the first longitudinal analysis of campaign sentiment in

\footnotetext{
13 It is worth noting that these results are based on a small number of cases and that variation is particularly low for some variables, such as extremeness and gender as only two extreme candidates and two women are represented in this sample.
} 
candidate-centered elections outside the USA. Leveraging the French case with two-round elections, it has further investigated how the strategic context of electoral rounds and candidate attributes affect campaign tone.

Unlike the USA, where negativity has been increasing over time (e.g., Geer 2006; West 2017), there is no evidence that elections have become more negative in France. Results further indicate that differences in campaign tone of first and second round elections are largely explained by candidate attributes. The presence (or absence) of extreme candidates or outsiders thus has a much stronger influence on campaign tone than the general strategic setup or objective conditions, such as economic growth. These results equally apply to the group of successful candidates.

The findings contribute to and enrich our understanding of electoral competition and have more general implications for society and perceptions of democratic quality. First, our results show that campaigns have not drifted toward the negative over time. This could be good news in the light of an ongoing debate about the role of negative politics in promoting polarization or democratic disaffection. While the general consequences of negative politics are still disputed, empirical evidence suggests that strongly negative or uncivil campaigns can undermine support for democracy, lead to a decline in voter turnout or promote polarization of voters with strong partisan attachment (Mutz and Reeves 2005; Lau et al. 2007; Haselmayer et al. 2020). Whereas the news media typically amplify negativity in election campaigns (Walter and Vliegenthart 2010; Haselmayer et al. 2019), which can distort public perceptions, our findings suggest that French presidential candidates are not responsible for an increase in negativity over the course of the past fifty years. Second, I find that candidate attributes rather than the strategic (institutional) setup of elections determines campaign sentiment. Whereas candidate behavior is obviously contingent on the institutional setup, the results of this study suggest that attributes of parties and candidates are most relevant for understanding campaign sentiment.

Albeit covering five decades and all direct French presidential elections, this study comes with limitations. First, it investigates a single communication channel, which might not be representative of the entire campaign and is unable to capture dynamics. Another reservation concerns the nature of the documents. Professions de foi have an incomparable penetration as they are sent out to all voters who are still using them to learn about the campaign (OpinionWay 2017). Yet, their electoral relevance is increasingly challenged by new forms of individualized campaigning, such as Facebook, Twitter or Instagram.

However, despite these trends, professions de foi summarize a candidates' campaign strategy before an election. They provide researchers with a unique opportunity to analyze the strategy of parties and candidates in the long term, which is not possible with more "contemporary" communication tools. Thereby, evidence from 
candidates' personal manifestos provides important insights and offers great potential for future research into the evolution of political campaigns.

Such studies could provide in-depth analyses on which factors shape variation of campaign sentiment across elections. In addition, future research could draw on manual content analysis, crowdcoding and machine learning to gather more finegrained information on the sentiment strength of manifestos (Haselmayer and Jenny 2018; Rudkowsky et al. 2018; Jenny et al. 2021). This could uncover, whether the relatively stable balance of positive and negative communication found in this study is masking an increase in uncivil or strongly negative campaign messages.

Beyond campaign tone, future research could exploit the wealth of information provided in the professions de foi to study other aspects of electoral competition, such as issue emphasis, spatial competition or electoral pledges. These data further lend themselves to comparisons with other data sources, such as party manifestos, which enables contrasting the electoral strategies of parties and candidates.

Finally, the manuscript has shown that the French version of the Lexicoder sentiment dictionary produces valid estimates for studies of political communication in France. Even for short texts and across 50 years of elections, the sentiment dictionary provides good results. This should encourage future research into the sentiment of political communication in election campaigns, parliamentary debates or media reports and thereby add to an emerging literature on the relevance and role of sentiment in contemporary politics (e.g., Haselmayer and Jenny 2017; Rudkowsky et al. 2018; Kosmidis et al. 2019; Crabtree et al. 2020; Traber et al. 2020).

\section{Appendix A}

See Tables 2, 3 and 4. 
Table 2 List of presidential candidates and ideological extremeness

\begin{tabular}{|c|c|c|c|}
\hline Candidate & Moderate & Extreme & Total \\
\hline Arthaud, Nathalie & 0 & 2 & 2 \\
\hline Asselineau, François & 1 & 0 & 1 \\
\hline Balladur, Édouard & 1 & 0 & 1 \\
\hline Barbu, Marcel & 1 & 0 & 1 \\
\hline Barre, Raymond & 1 & 0 & 1 \\
\hline Bayrou, François & 3 & 0 & 3 \\
\hline Besancenot, Olivier & 0 & 2 & 2 \\
\hline Bouchardeau, Huguette & 1 & 0 & 1 \\
\hline Boussel, Pierre & 0 & 1 & 1 \\
\hline Boutin, Christine & 1 & 0 & 1 \\
\hline Bové, José & 1 & 0 & 1 \\
\hline Buffet, Marie-Georges & 0 & 1 & 1 \\
\hline Chaban-Delmas, Jacques & 1 & 0 & 1 \\
\hline Cheminade, Jacques & 3 & 0 & 3 \\
\hline Chevènement, Jean-Pierre & 1 & 0 & 1 \\
\hline Chirac, Jacques & 7 & 0 & 7 \\
\hline Crépeau, Michel & 1 & 0 & 1 \\
\hline De Gaulle, Charles & 2 & 0 & 2 \\
\hline Debré, Michel & 1 & 0 & 1 \\
\hline Defferre, Gaston & 1 & 0 & 1 \\
\hline Ducatel, Louis & 1 & 0 & 1 \\
\hline Duclos, Jacques & 0 & 1 & 1 \\
\hline Dumont, René & 1 & 0 & 1 \\
\hline Dupont-Aignan, Nicolas & 1 & 1 & 2 \\
\hline Fillon, Francois & 1 & 0 & 1 \\
\hline Garaud, Marie-France & 1 & 0 & 1 \\
\hline Giscard d'Estaing, Valéry & 4 & 0 & 4 \\
\hline Gluckstein, Daniel & 0 & 1 & 1 \\
\hline Hamon, Benoît & 1 & 0 & 1 \\
\hline Heraud, Guy & 1 & 0 & 1 \\
\hline Hollande, François & 2 & 0 & 2 \\
\hline Hue, Robert & 0 & 2 & 2 \\
\hline Joly, Eva & 1 & 0 & 1 \\
\hline Jospin, Lionel & 3 & 0 & 3 \\
\hline Juquin, Pierre & 0 & 1 & 1 \\
\hline Krivine, Alain & 0 & 2 & 2 \\
\hline Laguiller, Arlette & 0 & 6 & 6 \\
\hline Lajoinie, André & 0 & 1 & 1 \\
\hline Lalonde, Brice & 1 & 0 & 1 \\
\hline Lassalle, Jean & 1 & 0 & 1 \\
\hline Le Pen, Jean-Marie & 0 & 5 & 5 \\
\hline Le Pen, Marine & 0 & 3 & 3 \\
\hline Lecanuet, Jean & 1 & 0 & 1 \\
\hline
\end{tabular}


Table 2 (continued)

\begin{tabular}{|c|c|c|c|}
\hline Candidate & Moderate & Extreme & Total \\
\hline Lepage, Corinne & 1 & 0 & 1 \\
\hline Macron, Emmanuel & 2 & 0 & 2 \\
\hline Madelin, Alain & 1 & 0 & 1 \\
\hline Mamère, Noël & 1 & 0 & 1 \\
\hline Marchais, Georges & 0 & 1 & 1 \\
\hline Marcilhacy, Pierre & 1 & 0 & 1 \\
\hline Mégret, Bruno & 0 & 1 & 1 \\
\hline Mélenchon, Jean-Luc & 0 & 2 & 2 \\
\hline Mitterrand, François & 8 & 0 & 8 \\
\hline Muller, Émile & 1 & 0 & 1 \\
\hline Nihous, Frédéric & 1 & 0 & 1 \\
\hline Poher, Alain & 2 & 0 & 2 \\
\hline Pompidou, Georges & 2 & 0 & 2 \\
\hline Poutou, Philippe & 0 & 2 & 2 \\
\hline Renouvin, Bertrand & 1 & 0 & 1 \\
\hline Rocard, Michel & 1 & 0 & 1 \\
\hline Royal, Ségolène & 2 & 0 & 2 \\
\hline Royer, Jean & 1 & 0 & 1 \\
\hline Saint-Josse, Jean & 1 & 0 & 1 \\
\hline Sarkozy, Nicolas & 4 & 0 & 4 \\
\hline Schivardi, Gérard & 0 & 1 & 1 \\
\hline Sebag, Jean-Claude & 1 & 0 & 1 \\
\hline Taubira, Christiane & 1 & 0 & 1 \\
\hline Tixier-Vignancour, Jean-Louis & 0 & 1 & 1 \\
\hline de Villiers, Philippe & 2 & 0 & 1 \\
\hline Voynet, Dominique & 2 & 0 & 2 \\
\hline Waechter, Antoine & 1 & 0 & 1 \\
\hline Total & 84 & 37 & 120 \\
\hline
\end{tabular}

Following expert judgments, Nicolas Dupont-Aignan has been coded as moderate in 2012 and extreme in the 2017 elections (Polk et al. 2017) 
Table 3 Descriptive information for the variables of interest (full sample)

Table 4 Descriptive information for the variables of interest (runner-offs)

\begin{tabular}{lrrll}
\hline Variable & \multicolumn{1}{l}{ Mean } & Std. Dev & Min & Max \\
\hline Campaign sentiment & 2.40 & 2.17 & -2.53 & 9.52 \\
Time count & 5.83 & 2.76 & 1 & 10 \\
Round & 0.17 & 0.37 & 0 & 1 \\
Ideological extremeness & 0.31 & 0.47 & 0 & 1 \\
Outsider (2\% of votes) & 0.29 & 0.46 & 0 & 1 \\
Gender & 0.19 & 0.39 & 0 & 1 \\
Cohabitation & 0.33 & 0.47 & 0 & 1 \\
Frontrunner & 0.17 & 0.37 & 0 & 1 \\
Length (words) & 1618.44 & 780.19 & 237 & 4064 \\
GDP growth (lagged) & 2.97 & 1.76 & 1.17 & 6.52 \\
\hline
\end{tabular}

\begin{tabular}{lrrll}
\hline Variable & Mean & Std. Dev & Min & Max \\
\hline Campaign sentiment & 3.97 & 1.96 & 0.34 & 9.52 \\
Ideological extremeness & 0.1 & 0.30 & 0 & 1 \\
Gender & 0.1 & 0.30 & 0 & 1 \\
Cohabitation & 0.3 & 0.46 & 0 & 1 \\
Frontrunner & 0.5 & 0.51 & 0 & 1 \\
Length (words) & 1111.18 & 711.02 & 248 & 4064 \\
GDP growth (lagged) & 3.13 & 1.84 & 1.17 & 6.52 \\
\hline
\end{tabular}




\section{Appendix B: Robustness tests}

See Tables 5, 6, 7 and 8 .

Table 5 Explaining campaign sentiment in French Presidential elections (1965-2017) using bootstrapped standard errors

\begin{tabular}{|c|c|c|c|c|}
\hline & Model 1 & Model 2 & Model 3 & Model 4 \\
\hline Time trend & $\begin{array}{l}-0.08 \\
(0.10)\end{array}$ & $\begin{array}{l}-0.01 \\
(0.08)\end{array}$ & $\begin{array}{l}-0.10 \\
(0.24)\end{array}$ & $\begin{array}{l}-0.13 \\
(0.20)\end{array}$ \\
\hline Election round & $\begin{array}{l}1.10^{*} \\
(0.54)\end{array}$ & $\begin{array}{l}0.21 \\
(0.63)\end{array}$ & $\begin{array}{l}-0.17 \\
(0.65)\end{array}$ & $\begin{array}{l}-0.06 \\
(0.59)\end{array}$ \\
\hline Extreme & - & $\begin{array}{l}-1.65^{* * *} \\
(0.34)\end{array}$ & - & $\begin{array}{l}-0.58 \\
(0.68)\end{array}$ \\
\hline Outsider & - & $\begin{array}{l}-0.97 * * \\
(0.37)\end{array}$ & - & - \\
\hline Frontrunner & - & $\begin{array}{l}1.65 * * \\
(0.58)\end{array}$ & - & $\begin{array}{l}1.87 * * \\
(0.71)\end{array}$ \\
\hline Female & - & $\begin{array}{l}0.23 \\
(0.43)\end{array}$ & - & $\begin{array}{l}0.79 \\
(1.00)\end{array}$ \\
\hline Cohabitation & $\begin{array}{l}-0.07 \\
(0.37)\end{array}$ & $\begin{array}{l}-0.03 \\
(0.36)\end{array}$ & $\begin{array}{l}0.10 \\
(0.85)\end{array}$ & $\begin{array}{l}0.33 \\
(0.85)\end{array}$ \\
\hline GDP growth (lagged) & $\begin{array}{l}-0.01 \\
(0.19)\end{array}$ & $\begin{array}{l}0.03 \\
(0.16)\end{array}$ & $\begin{array}{l}0.07 \\
(0.43)\end{array}$ & $\begin{array}{l}0.04 \\
(0.40)\end{array}$ \\
\hline Text length & $\begin{array}{l}-0.00^{* * * *} \\
(0.00)\end{array}$ & $\begin{array}{l}-0.00^{+} \\
(0.00)\end{array}$ & $\begin{array}{l}-0.00 * \\
(0.00)\end{array}$ & $\begin{array}{l}-0.00 * \\
(0.00)\end{array}$ \\
\hline Constant & $\begin{array}{l}4.46^{* * * *} \\
(1.10)\end{array}$ & $\begin{array}{l}3.74 * * * \\
(0.91)\end{array}$ & $\begin{array}{l}5.51^{+} \\
(3.00)\end{array}$ & $\begin{array}{l}4.53^{+} \\
(2.69)\end{array}$ \\
\hline Observations & 121 & 121 & 40 & 40 \\
\hline Adjusted $R^{2}$ & 0.23 & 0.48 & 0.08 & 0.28 \\
\hline
\end{tabular}

Bootstrapped standard errors (50 replications) in parentheses, ${ }^{+} p<0.10, * p<0.05, * * p<0.01, * * * p<0.001$ 
Table 6 Explaining campaign sentiment in French Presidential elections (1965-2017): negative campaign sentiment

\begin{tabular}{lllll}
\hline & Model 1 & Model 2 & Model 3 & Model 4 \\
\hline Time trend & 0.05 & 0.02 & -0.06 & -0.09 \\
& $(0.05)$ & $(0.06)$ & $(0.08)$ & $(0.09)$ \\
Election round & -0.24 & 0.10 & 0.38 & 0.38 \\
Extreme & $(0.24)$ & $(0.20)$ & $(0.25)$ & $(0.25)$ \\
& - & $0.51^{*}$ & - & -0.09 \\
Outsider & & $(0.20)$ & & $(0.47)$ \\
& - & 0.34 & - & - \\
Frontrunner & & $(0.21)$ & & \\
& - & $-0.67^{* *}$ & - & $-0.59^{+}$ \\
Female & & $(0.25)$ & & $(0.28)$ \\
& - & -0.07 & - & 0.59 \\
Cohabitation & & $(0.22)$ & & $(0.49)$ \\
& -0.04 & -0.05 & -0.24 & -0.13 \\
GDP growth (lagged) & -0.03 & -0.04 & $-0.34^{* *}$ & $-0.35^{*}$ \\
& $(0.10)$ & $(0.11)$ & $(0.09)$ & $(0.16)$ \\
Text length & $0.00^{*}$ & 0.00 & $0.00^{*}$ & $0.00^{* *}$ \\
& $(0.00)$ & $(0.00)$ & $(0.00)$ & $(0.00)$ \\
Constant & $2.33^{* * *}$ & $2.59^{* * *}$ & $3.16^{* * *}$ & $3.52^{* * *}$ \\
& $(0.52)$ & $(0.56)$ & $(0.59)$ & $(0.77)$ \\
Observations & 121 & 121 & 40 & 40 \\
Adjusted $R^{2}$ & 0.08 & 0.22 & 0.23 & 0.36 \\
\hline
\end{tabular}

Candidate-clustered standard errors in parentheses, ${ }^{+} p<0.10$, ${ }^{*} p<0.05,{ }^{* *} p<0.01,{ }^{* * *} p<0.001$ 
Table 7 Explaining campaign sentiment in French Presidential elections (1965-2017): positive campaign sentiment

\begin{tabular}{|c|c|c|c|c|}
\hline & Model 1 & Model 2 & Model 3 & Model 4 \\
\hline Time trend & $\begin{array}{l}-0.03 \\
(0.08)\end{array}$ & $\begin{array}{l}0.01 \\
(0.07)\end{array}$ & $\begin{array}{l}-0.16 \\
(0.19)\end{array}$ & $\begin{array}{l}-0.22 \\
(0.13)\end{array}$ \\
\hline Election round & $\begin{array}{l}0.86^{+} \\
(0.45)\end{array}$ & $\begin{array}{l}0.31 \\
(0.51)\end{array}$ & $\begin{array}{l}0.21 \\
(0.59)\end{array}$ & $\begin{array}{l}0.32 \\
(0.56)\end{array}$ \\
\hline Extreme & - & $\begin{array}{l}-1.14^{* * *} \\
(0.29)\end{array}$ & - & $\begin{array}{l}-0.67^{+} \\
(0.34)\end{array}$ \\
\hline Outsider & - & $\begin{array}{l}-0.63^{*} \\
(0.27)\end{array}$ & - & - \\
\hline Frontrunner & - & $\begin{array}{l}0.98^{*} \\
(0.43)\end{array}$ & - & $\begin{array}{l}1.28 * \\
(0.53)\end{array}$ \\
\hline Female & - & $\begin{array}{l}0.16 \\
(0.40)\end{array}$ & - & $\begin{array}{l}1.37^{+} \\
(0.65)\end{array}$ \\
\hline Cohabitation & $\begin{array}{l}-0.11 \\
(0.33)\end{array}$ & $\begin{array}{l}-0.08 \\
(0.26)\end{array}$ & $\begin{array}{l}-0.13 \\
(0.80)\end{array}$ & $\begin{array}{l}0.20 \\
(0.62)\end{array}$ \\
\hline GDP growth (lagged) & $\begin{array}{l}-0.04 \\
(0.15)\end{array}$ & $\begin{array}{l}-0.01 \\
(0.12)\end{array}$ & $\begin{array}{l}-0.27 \\
(0.35)\end{array}$ & $\begin{array}{l}-0.30^{+} \\
(0.16)\end{array}$ \\
\hline Text length & $\begin{array}{l}-0.00^{* * *} \\
(0.00)\end{array}$ & $\begin{array}{l}-0.00 * \\
(0.00)\end{array}$ & $\begin{array}{l}-0.00^{*} \\
(0.00)\end{array}$ & $\begin{array}{l}-0.00^{+} \\
(0.00)\end{array}$ \\
\hline Constant & $\begin{array}{l}6.79 * * * \\
(0.98)\end{array}$ & $\begin{array}{l}6.33^{* * * *} \\
(0.75)\end{array}$ & $\begin{array}{l}8.67 * * \\
(2.26)\end{array}$ & $\begin{array}{l}8.05^{* * *} \\
(1.40)\end{array}$ \\
\hline Observations & 121 & 121 & 40 & 40 \\
\hline Adjusted $R^{2}$ & 0.23 & 0.41 & 0.04 & 0.18 \\
\hline
\end{tabular}

Candidate-clustered standard errors in parentheses, ${ }^{+} p<0.10$, ${ }^{*} p<0.05, * * p<0.01, * * * p<0.001$ 
Table 8 Explaining campaign sentiment in French Presidential elections (1965-2017): using different thresholds for outsider candidates

\begin{tabular}{|c|c|c|c|c|}
\hline & $\begin{array}{l}\text { Model 2a (paper) (2\% } \\
\text { threshold) }\end{array}$ & $\begin{array}{l}\text { Model 2b (1\% } \\
\text { threshold) }\end{array}$ & $\begin{array}{l}\text { Model 2c (3\% } \\
\text { threshold) }\end{array}$ & $\begin{array}{l}\text { Model 2d } \\
\text { (5\% thresh- } \\
\text { old) }\end{array}$ \\
\hline Time trend & $\begin{array}{l}-0.01 \\
(0.09)\end{array}$ & $\begin{array}{l}-0.00 \\
(0.10)\end{array}$ & $\begin{array}{l}-0.03 \\
(0.09)\end{array}$ & $\begin{array}{l}-0.03 \\
(0.09)\end{array}$ \\
\hline Election round & $\begin{array}{l}0.21 \\
(0.61)\end{array}$ & $\begin{array}{l}0.36 \\
(0.61)\end{array}$ & $\begin{array}{l}0.18 \\
(0.61)\end{array}$ & $\begin{array}{l}0.05 \\
(0.61)\end{array}$ \\
\hline Extreme & $\begin{array}{l}-1.65^{* * *} \\
(0.32)\end{array}$ & $\begin{array}{l}-1.56^{* * *} \\
(0.35)\end{array}$ & $\begin{array}{l}-1.58^{* * * *} \\
(0.32)\end{array}$ & $\begin{array}{l}-1.60 * * * \\
(0.30)\end{array}$ \\
\hline Outsider & $\begin{array}{l}-0.97 * \\
(0.38)\end{array}$ & $\begin{array}{l}-0.77^{+} \\
(0.42)\end{array}$ & $\begin{array}{l}-0.89^{*} \\
(0.36)\end{array}$ & $\begin{array}{l}-1.15^{* * *} \\
(0.32)\end{array}$ \\
\hline Frontrunner & $\begin{array}{l}1.65^{* * *} \\
(0.40)\end{array}$ & $\begin{array}{l}1.79 * * * \\
(0.42)\end{array}$ & $\begin{array}{l}1.65^{* * *} \\
(0.40)\end{array}$ & $\begin{array}{l}1.49^{* * *} \\
(0.39)\end{array}$ \\
\hline Female & $\begin{array}{l}0.23 \\
(0.37)\end{array}$ & $\begin{array}{l}0.04 \\
(0.39)\end{array}$ & $\begin{array}{l}0.32 \\
(0.37)\end{array}$ & $\begin{array}{l}0.29 \\
(0.36)\end{array}$ \\
\hline Cohabitation & $\begin{array}{l}-0.03 \\
(0.32)\end{array}$ & $\begin{array}{l}0.12 \\
(0.32)\end{array}$ & $\begin{array}{l}-0.02 \\
(0.34)\end{array}$ & $\begin{array}{l}0.02 \\
(0.32)\end{array}$ \\
\hline GDP growh (lagged) & $\begin{array}{l}0.03 \\
(0.14)\end{array}$ & $\begin{array}{l}0.04 \\
(0.15)\end{array}$ & $\begin{array}{l}0.01 \\
(0.14)\end{array}$ & $\begin{array}{l}0.00 \\
(0.14)\end{array}$ \\
\hline Text length & $\begin{array}{l}-0.00^{*} \\
(0.00)\end{array}$ & $\begin{array}{l}-0.00^{*} \\
(0.00)\end{array}$ & $\begin{array}{l}-0.00^{*} \\
(0.00)\end{array}$ & $\begin{array}{l}-0.00^{*} \\
(0.00)\end{array}$ \\
\hline Constant & $\begin{array}{l}3.74 * * * \\
(0.97)\end{array}$ & $\begin{array}{l}3.43 * * * \\
(0.93)\end{array}$ & $\begin{array}{l}3.92 * * * \\
(0.96)\end{array}$ & $\begin{array}{l}4.11^{* * *} \\
(0.97)\end{array}$ \\
\hline Observations & 121 & 121 & 121 & 121 \\
\hline Adjusted $R^{2}$ & 0.48 & 0.46 & 0.47 & 0.50 \\
\hline
\end{tabular}

Candidate-clustered standard errors in parentheses, ${ }^{+} p<0.10,{ }^{*} p<0.05, * * p<0.01,{ }^{* * *} p<0.001$

\section{Appendix C: Additional validation of the French Lexicoder Sentiment Dictionary}

In addition to the validation in the paper, the dictionary scores were compared to human coding decisions at the level of sentences. To mirror human coding, I recoded the dictionary scores to a three-valued indicator variable (negative, neutral, positive). Sentences with a majority of positive words were coded positive, and those containing more negative than positive entries were negative. Neutral sentences either had no dictionary match or an equal number of positive and negative entries. I than compared the sentiment determined by the dictionary to the majority decision of human coders. 
Overall, the dictionary was able to detect the correct sentiment for 72 out of 100 sentences (Spearman's rank correlation of 0.66). Calculating a confusion matrix resulted in an F-score of 0.69 (precision $=0.71$, recall=0.69). ${ }^{14}$ These are good results at this stage of analysis, keeping in mind that the dictionary was designed for analyzing larger text units, such as entire news articles.

To inspect if the dictionary is able to detect sentiment across the fifty years of election campaigns under study, I aggregated elections to decades. The ratio of correctly predicted sentiment scores ranges from 60 percent (1990s and 2000s) to about 80 percent (1960s, 1980s and 2010s), which suggests that the dictionary is able to detect sentiment during the research period. The observation of time-independency is corroborated when I aggregate the data to two decade-units resulting in ratios of correctly predicted cases ranging from 71 percent (2000-2019 to 75 percent (1980-1999).

Acknowledgements I would like to thank Odile Gaultier-Voituriez for introducing me to the CEVIPOF electoral archives and Maximilian Böck for excellent research assistance. I am also grateful for comments and input provided by two anonymous reviewers.

Funding Open Access funding enabled and organized by Projekt DEAL.

Open Access This article is licensed under a Creative Commons Attribution 4.0 International License, which permits use, sharing, adaptation, distribution and reproduction in any medium or format, as long as you give appropriate credit to the original author(s) and the source, provide a link to the Creative Commons licence, and indicate if changes were made. The images or other third party material in this article are included in the article's Creative Commons licence, unless indicated otherwise in a credit line to the material. If material is not included in the article's Creative Commons licence and your intended use is not permitted by statutory regulation or exceeds the permitted use, you will need to obtain permission directly from the copyright holder. To view a copy of this licence, visit http://creativecommons.org/licen ses/by/4.0/.

\section{References}

Benoit, K., K. Watanabe, H. Wang, P. Nulty, A. Obeng, S. Müller, and A. Matsuo. 2018. Quanteda: An R Package for the Quantitative Analysis of Textual Data. Journal of Open Source Software 3(30): 774. Bonhomme, M. 2016. Les Professions de foi à l'Occasion des Élections Présidentielles Françaises. Mots. Les Langages Du Politique 3: 21-27.

Brader, T. 2005. Striking a Responsive Chord: How Political Ads Motivate and Persuade Voters by Appealing to Emotions. American Journal of Political Science 49(2): 388-405.

Brader, T. 2006. Campaigning for Hearts and Minds: How Emotional Appeals in Political Ads Work. Chicago: University of Chicago Press.

Chong, D., and J.N. Druckman. 2007. Framing Theory. Annual Review of Political Science 10: 103-126.

\footnotetext{
14 Precision indicates the fraction of true positive sentences in the number of all sentences predicted as positive and thereby compares it against incorrectly predicted ones (or false positives). Recall compares the number of sentences with predicted positive sentiment against the true number of positive sentences, which accounts for "missed" positive sentences (or false negatives).
} 
Crabtree, C., M. Golder, T. Gschwend, and I.H. Indridason. 2020. It Is Not Only What You Say, It Is Also How You Say It: The Strategic Use of Campaign Sentiment. The Journal of Politics 82(3): 1044-1060.

De Condorcet, N.A. 1785. Essai sur l'application de l'analyse à la probabilité des décisions rendues à la pluralité des voix. Paris: Imprimerie Royale.

Gougou, F., and S. Persico. 2017. A New Party System in the Making? The 2017 French Presidential Election. French Politics 15(3): 303-321.

Gougou, F., and S. Labouret. 2013. La fin de la Tripartition? Revue Française De Science Politique 63(2): 279-302.

Druckman, J.N. 2004. Politcal Preference Formation: Competition, Deliberation, and The (Ir)relevance of Framing Effects. American Political Science Review 98(4): 671-686.

Duverger, M. 1951. Les partis politiques. Paris: Colin.

Esquenazi, J.-P. 2003. Lionel Jospin Et La Campagne De 2002. Erreur De Communication Ou Erreur Politique? Vingtieme Siecle. Revue D'histoire 80: 101-112.

Galtung, J., and M. Holmboe Ruge. 1965. The Structure of Foreign News: The Presentation of the Congo, Cuba and Cyprus Crises in Four Foreign Newspapers. Journal of Peace Research 2(1): 64-91.

Geer, J.G. 2006. In Defense of Negativity: Attack Ads in Presidential Campaigns. University of Chicago Press.

Haselmayer, M., L. Hirsch, and M. Jenny. 2020. Love is Blind. Partisanship and Perception of Negative Campaign Messages in a Multiparty System. Political Research Exchange 2(1): 1-17.

Haselmayer, M. 2019. Negative Campaigning and Its Consequences: A Review and a Look Ahead. French Politics 17(3): 355-372.

Haselmayer, M., T.M. Meyer, and M. Wagner. 2019. Fighting for Attention: Media Coverage of Negative Campaign Messages. Party Politics 25(3): 412-423.

Haselmayer, M., and M. Jenny. 2018. Friendly Fire? Negative Campaigning Among Coalition Partners. Research \& Politics 5(3): 1-9.

Haselmayer, M., and M. Jenny. 2017. Sentiment Analysis of Political Communication: Combining a Dictionary Approach with Crowdcoding. Quality \& Quantity 51(6): 2623-2646.

Jaffré, J. 2003. Comprendre L'élimination De Lionel Jospin. In Le Vote De Tous Les Refus. Les Élections Présidentielles Et Législatives De 2002, ed. P. Pascal and C. Ysmal, 199-220. Paris: Presses de Sciences-Po.

Jenny, M., M. Haselmayer, and D. Kapla. 2021. Measuring incivility in parliamentary debates: Validating a sentiment analysis procedure with Calls to Order in the Austrian Parliament. In Crossing boundaries: Political Incivility in the Parliamentary, Electoral and Media Arena, ed. A. Walter, 56-66. Abingdon: Routledge.

Kosmidis, S., S.B. Hobolt, E. Molloy, and S. Whitefield. 2019. Party Competition and Emotive Rhetoric. Comparative Political Studies 52(6): 811-837.

Labbé, L., and D. Monière. 2014. Ne votez pas pour l'autre ! La spirale de la négativité. In la campagne présidentielle. Observer les médias des électeurs et des candidats, ed. J. Gerstlé and M.G. Berton, 195-210. Paris: L'Harmattan.

Lau, R.R., and I. Brown Rovner. 2009. Negative Campaigning. Annual Review of Political Science 12: 285-306.

Lau, R.R., L. Sigelman, and I. Brown Rovner. 2007. The Effects of Negative Political Campaigns: A Meta-analytic Reassessment. The Journal of Politics 69(4): 1176-1209.

Laver, M., K. Benoit, and N. Sauger. 2006. Policy Competition in the 2002 French Legislative and Presidential Elections. European Journal of Political Research 45(4): 667-697.

Lévêque, S. 2005. La Féminité «Dépassée»? Usages et Non-usages du Genre Dans les Professions de foi des Candidat(e)s Parisien(ne)s Aux Élections Législatives de 2002. Revue Française De Science Politique 55(3): 501-520.

Marcus, G.E. 2010. Sentimental Citizen: Emotion in Democratic Politics. Philadelphia: University of Pennsylvania Press.

Marcus, G.E. 2000. Emotions in Politics. Annual Review of Political Science 3(1): 221-250.

Morin, A., and C. Sourd. 2007. Usages et Usagers du Mot Démocratie et de Ses Dérivés. Une Étude Des Professions de foi des Candidats aux Élections Législatives et Cantonales. Mots. Les Langages Du Politiques 83: 23-35.

Nai, A., and A. Walter, eds. 2015. New Perspectives on Negative Campaigning: Why Attack Politics Matters. Colchester: ECPR Press. 
OpinionWay. 2017. Sondage Jour Du Vote. Premier Tour Des Élections Législatives 2017.

Pennebaker, J.W., and M.E. Francis. 1996. Cognitive, Emotional, and Language Processes in Disclosure. Cognition \& Emotion 10(6): 601-626.

Plasser, F., and G. Plasser. 2002. Global Political Campaigning: A Worldwide Analysis of Campaign Professionals and Their Practices. Westport: Greenwood Publishing Group.

Polk, J., J. Rovny, R. Bakker, E. Edwards, L. Hooghe, S. Jolly, J. Koedam, F. Kostelka, G. Marks, G. Schumacher, M. Steenbergen, M. Vachudova, and M. Zilovic. 2017. Explaining the Salience of Anti-elitism and Reducing Political Corruption for Political Parties in Europe with the 2014 Chapel Hill Expert Survey Data. Research \& Politics 4(1): 1-9.

Rampon, J.-M. 2006. Professions de foi et Élection Présidentielle de 2002. Une Approche Verbale de la Distance Entre Candidats. Mots. Les Langages Du Politiques 81: 93-108.

Rigat, F. 2010. «Mes Chers Compatriotes»: Stratégies Discursives de l'Interpellation des Electeurs Dans les Professions de Foi. Corela. Cognition, Représentation, Langage, HS-8.

Rudkowsky, E., M. Haselmayer, M. Wastian, M. Jenny, Š Emrich, and M. Sedlmair. 2018. More than Bags of Words: Sentiment Analysis with Word Embeddings. Communication Methods and Measures 12(2-3): 140-157.

Soroka, S.N. 2014. Negativity in Democratic Politics: Causes and Consequences. New York: Cambridge University Press.

Stokes, D.E. 1963. Spatial Models of Party Competition. American Political Science Review 57(2): 368-377.

Traber, D., M. Schoonvelde, and G. Schumacher. 2020. Errors have been Made, Others will be Blamed: Issue Engagement and Blame Shifting in Prime Minister Speeches During the Economic Crisis in Europe. European Journal of Political Research 59(1): 45-67.

Tversky, A., and D. Kahneman. 1981. The Framing of Decisions and the Psychology of Choice. Science 211(4481): 453-458.

Valli, C., \& Nai, A. 2020. Attack Politics from Albania to Zimbabwe: A Large-Scale Comparative Study on the Drivers of Negative Campaigning. International Political Science Review. Online first.

Young, L., and S. Soroka. 2012. Affective News: The Automated Coding of Sentiment in Political Texts. Political Communication 29(2): 205-231.

Walter. 2014. Negative Campaigning in Western Europe: Similar or Different? Political Studies 62(S1): $42-60$.

Walter, A.S., W. Van der Brug, and P. van Praag. 2014. When the Stakes are High: Party Competition and Negative Campaigning. Comparative Political Studies 47(4): 550-573.

Walter, A.S., and R. Vliegenthart. 2010. Negative Campaigning Across Different Communication Channels: Different Ball Games? The International Journal of Press/politics 15(4): 441-461.

West, D.M. 2017. Air Wars: Television Advertising and Social Media in Election Campaigns, 19522016. Washington DC: CQ Press.

World Bank. 2021. Databank.World Bank Open Data. https://data.worldbank.org.

Publisher's Note Springer Nature remains neutral with regard to jurisdictional claims in published maps and institutional affiliations. 